\title{
ETHYLENE IN THE CONTROL OF PHOTOPERIODIC FLOWER INDUCTION IN PHARBITIS NIL CHOIS.
}

\author{
HALINA KULIKOWSKA-GULEWSKA, JAN KOPCEWICZ
}

\author{
Department of Plant Physiology and Morphogenesis, \\ Institute of General and Molecular Biology, Nicolaus Copernicus University, \\ 87-100 Toruń, Gagarina 9
}

(Received: April 23, 1998. Accepted: October 5, 1998)

\begin{abstract}
The content of endogenous ethylene in the seedlings of Pharbitis nil subjected to 16-hour long inductive night is low during the first half of a dark period, then it increases considerably in the second half of the night. Ethrel, the compound releasing ethylene, applied to the cotyledons of the seedlings, increases the amount of endogenous ethylene in them and at the same time inhibits the flowering, especially when ethrel was applied during the first half of an inductive night, when the content of endogenous ethylene in the seedlings is low. The auxin, inhibiting the flowering of Pharbitis, causes at the same time the increase in the production of endogenous ethylene. PCIB, an inhibitor of auxin action, reverses the inhibiting influence of ethrel on flowering. On the other hand the combined application of ethrel and TIBA, the inhibitor of auxin polar transport, causes the increase of the flowering inhibition. $\mathrm{CoCl}_{2}$, the inhibitor of ethylene biosynthesis, and $\mathrm{AgNO}_{3}$, the inhibitor of ethylene action, reverse partly the inhibiting influence of auxin. It suggests that ethylene could take part in auxininhibition of flowering. The all obtained results seem to suggest the participation of ethylene in the control of the flower photoperiodic induction.
\end{abstract}

KEY WORDS: ethylene, auxin, photoperiodic induction, Pharbitis nil.

\section{INTRODUCTION}

Ethylene may stimulate flowering in pineapple (Rodriguez 1932), mango (Galang 1936) and plants from Bromeliaceae family (Gaspar et al. 1986). It may also inhibit the flowering of short-day plants, such as Pharbitis nil (Suge and Amagasa 1987), Chrysanthemum (Cockshull et al. 1967), Xanthium (Abeles 1967) or Chenopodium rubrum (Khatoon et al. 1967). The application of ethylene during a long inductive night inhibits the flowering of Pharbitis nil (Suge 1974). The influence of ethylene depends clearly on the applied concentration. The concentration of $100 \mathrm{ppm}$ is strongly inhibiting, whereas low concentrations of ethylene inhibit the formation of an apical bud, but do not influence the total number of flower buds per plant (Suge 1974). It seems that very low concentrations of ethylene may be even simply necessary for the induction of flowering (Halevy et al. 1991). It is commonly known that there are various correlations between auxin and ethylene in plants. Auxin exerts also great influence on ethylene production probably through the induction of ACC synthesis (Yoshi and Imaseki 1981; Smith and Hall 1984). In this situation ethylene may play the role of a secondary transmitter in the mechanism of auxin action

\section{Abbreviations}

IAA - indole-3-acetic acid; TIBA - 2, 3, 5-triiodobenzoic acid; PCIB - p.-choloro-phenoxyisobutyric acid; ACC - 1-aminocyclopropane-1-carboxylic acid; ethrel - 2-chloroethylphosphonic acid
(Abeles et al. 1992). Ethylene may also regulate the endogenous level of auxins through specific feedback (Abeles et al. 1992). The role of ethylene in auxin inhibition of flowering in short-day plants is controversial. In case of Chenopodium rubrum (Machackova et al. 1986) the auxin acts through increasing the ethylene production, whereas in case of Pharbitis nil (Halevy et al. 1991) such a dependence has not been established. Thus, in the present work, the attempt has been undertaken to determine the role of ethylene and its interrelation with auxin in the photoperiodic induction of flowering of a short-day plant Pharbitis nil.

\section{MATERIAL AND METHODS}

Seeds of Pharbitis nil Chois. cv. Violet (Marutane seed Co., Kyoto, Japan) were stirred with concentrated $\mathrm{H}_{2} \mathrm{SO}_{4}$ for 1 hour, rinsed well and imbibed for $24 \mathrm{~h}$ in distilled water $\left(25^{\circ} \mathrm{C}\right)$. The swollen seeds were sown into pots filled with perlite: sterile sand $(2: 1)$. There were 15 seeds in each pot. The pots were transferred to a growth chamber at $25^{\circ}$ with continuous irradiance $\left(18.3 \mathrm{~W} \mathrm{~m}^{-2}\right.$, cool white fluorescent tubes, Polam, Warsaw, Poland) for 4 days. On the 5th day from sowing the seedlings were subjected to photoperiodic induction, that is $16 \mathrm{~h}$ long inductive night. During the dark period (or sometimes also during light before and after inductive night) the plants were treated with plant growth regulators, which were applied to the cotyledons with a small soft 
brush (100 $\mathrm{mm}^{3}$ per plant). The applied chemicals were:ethrel, the compound evolving ethylene $\left(300 \mathrm{mg}^{*} \mathrm{dm}^{-3}\right.$, $400 \mathrm{mg}^{*} \mathrm{dm}^{-3}$ and $\left.500 \mathrm{mg}^{*} \mathrm{dm}^{-3}\right)$, IAA $\left(10^{-3} \mathrm{~mol}^{*} \mathrm{dm}^{-3}\right)$, auxin polar transport inhibitor TIBA $\left(10^{-3} \mathrm{~mol}^{*} \mathrm{dm}^{-3}\right)$, auxin action inhibitor PCIB $\left(10^{-3} \mathrm{~mol}^{*} \mathrm{dm}^{-3}\right)$, ethylene action inhibitor, silver nitrate $\mathrm{AgNO}_{3}\left(10^{-3} \mathrm{~mol}^{*} \mathrm{dm}^{-3}\right)$ and ethylene biosynthesis inhibitor, cobalt chloride $\mathrm{CoCl}_{2}\left(10^{-3} \mathrm{~mol}^{*} \mathrm{dm}^{-3}\right)$. Control plants were treated with distilled water. After the end of an inductive night the plants were grown in a growth chamber under continuous light at $25^{\circ} \mathrm{C}$ for 14 days. The number of floral buds per plant and the percentage of plants exhibiting terminal flowering were then determined using dissection microscope. As flowering plants we considered the plants with at least 4 floral buds. Each experiment was repeated at least 3 times. Standard errors were calculated.

\section{Determination of endogenous ethylene}

The seedlings of Pharbitis nil (5 days old) were put into glass jars, each of $370 \mathrm{~cm}^{3}$ volume (15 plants per jar). The average fresh weight was $9 \mathrm{~g}$ and the volume was $20 \mathrm{~cm}^{3}$. The seedling roots were sunk in $50 \mathrm{~cm}^{3}$ of distilled water. The jars were sealed with plastic caps and evolving ethylene was collected after the incubation period by means of a syringe and determined by gas chromatography (according to Michniewicz and Rożej 1989) on Shimadzu GC 148 equipped with a capilar column DB-5, $30 \mathrm{~m}$ long, $0.137 \mathrm{~mm}$ in diameter with temperature $50^{\circ} \mathrm{C}$. The temperature of injector heaters and of the oven was set at $+150^{\circ} \mathrm{C}$. The nitrogen carrier gas flow rate was $2 \mathrm{~cm}^{3 *} \mathrm{~min}^{-1}$. The retention time for ethylene was $1 \min 15 \mathrm{~s}$. The amount of endogenous ethylene was established on the basis of dose - response curve and calculated on $1 \mathrm{~g}$ of fresh weight per 1 hour, according to a scheme:

$$
\mathrm{x}=\frac{\mathrm{a} * \mathrm{v}}{\mathrm{m} * \mathrm{~h}}
$$

$\mathrm{x}$ - endogenous ethylene content $\left(\mathrm{nmol}^{*} \mathrm{~g}^{-1} \mathrm{~h}^{-1}\right.$ )

a - ethylene concentration calculated from dose - response curve

$\mathrm{v}$ - the glass jar volume, where ethylene was evolved (300 $\mathrm{cm}^{3}=$ jar volume - plant volume - distilled water volume)

$\mathrm{m}$ - average fresh weight of plants $(9 \mathrm{~g})$

$\mathrm{h}$ - number of hours of the incubation

The content of ethylene was expressed in $\mathrm{nM}^{*} \mathrm{~g}^{-1 * \mathrm{~h}^{-1}}$.

The presented results were obtained from three independent experiments. The results were statistically eveluated and LSD was calculated at significance level of 0.01 and 0.05 .

\section{RESULTS}

The content of endogenous ethylene in the seedlings of Pharbitis nil was low during the first half of a 16 - hour long

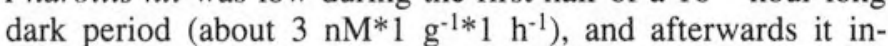
creased in the second half of the night to about $10 \mathrm{nM}^{*} 1 \mathrm{~g}^{-1 * 1}$ $\mathrm{h}^{-1}$ (Fig. 1). After the application of ethrel, a compound releasing ethylene (at the concentrations of $300 \mathrm{mg}^{*} \mathrm{dm}^{-3}, 400$ $\mathrm{mg} * \mathrm{dm}^{-3}$ and $500 \mathrm{mg}^{*} \mathrm{dm}^{-3}$ ), an increase in the production of endogenous ethylene by the seedlings of Pharbitis nil took place, both in the first and in the second half of the inductive dark period (Fig. 2). At the same time the number of flower buds per plant decreased dramatically from 6 for controls to

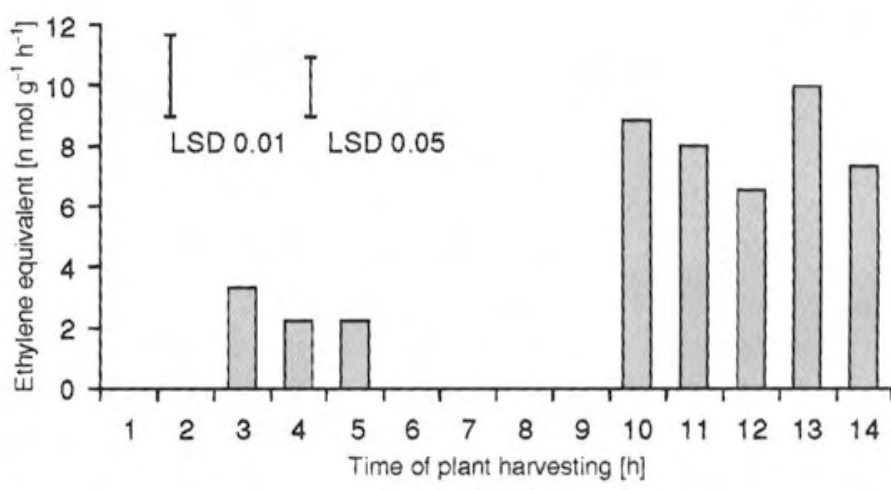

Fig. 1. Content of endogenous ethylene in Pharbitis nil seedlings during $16 \mathrm{~h}-$ long inductive night.

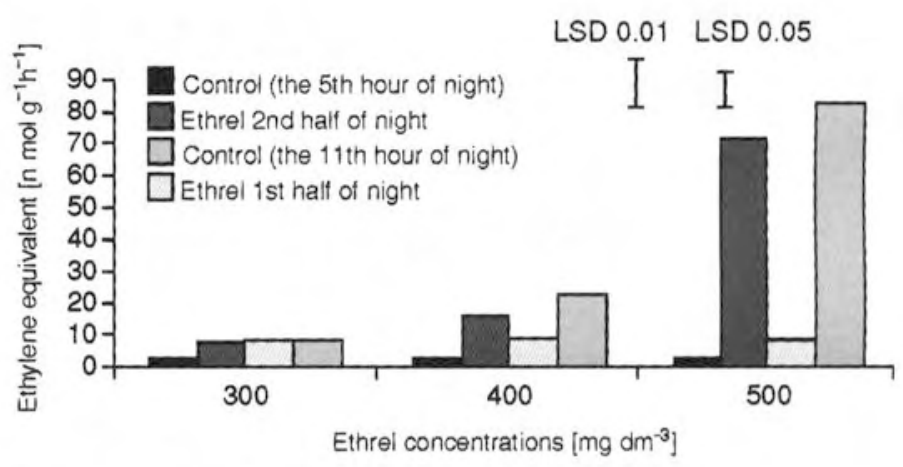

Fig. 2. Endogenous ethylene production by Pharbitis nil seedlings after ethrel application.

Ethrel was applied to cotyledones on the $5^{\text {th }}$ and $11^{\text {th }}$ hour of inductive night, that is during the first and second half of $16 \mathrm{~h}$ long dark period.

1.5 for treated seedlings especially during the first half of the inductive night. The percentage of plants with terminal flower bud decreased from about $90 \%$ for controls to about $20 \%$ for treated plants in the 4th and 8th hour of inductive night. Around the 16th hour of the dark period ethrel did not exert any inhibiting influence on flowering (Fig $3 \mathrm{~A}$ and B). In order to investigate the dependence between the application of auxin and the production of ethylene, the seedlings of Pharbitis nil were treated with auxin (IAA $10^{-3} \mathrm{M}^{*} \mathrm{dm}^{-3}$ ) every hour and the releasing ethylene was measured. The level of the ethylene underwent cyclic fluctuations during $16 \mathrm{~h}$ of the inductive dark period. Its content was very high in the first 2 hours of the inductive night, then it was decreased reaching the lowest values between the 3rd and the 6th hour of darkness and again it increased between the 7 th and the 10th hour of night (Fig. 4). The simultaneous application of ethrel (to cotyledons) and PCIB (to shoot tips) caused the increase in the number of flower buds. PCIB, the inhibitor of auxin action, reversed the inhibiting influence of the exogenous ethylene in the first 4 hours of an inductive night. However, during the 8th through 16th hour of the dark period it did not exert any influence (Fig. 5). The joint application of TIBA, the auxin polar transport inhibitor (on cotyledon petioles) and ethrel (on cotyledons) caused a strong inhibition of generative induction, particularly in the 0th, 4th, 8th and 12th hour of darkness (Fig. 6).The plants were also treated with IAA and then after 30 minutes with $\mathrm{CoCl}_{2}$, the inhibitor of ethylene biosynthesis. The inhibiting influence of auxin was partially reversed by $\mathrm{CoCl}_{2}$ at 0 th, 4th and 8th hour of night 

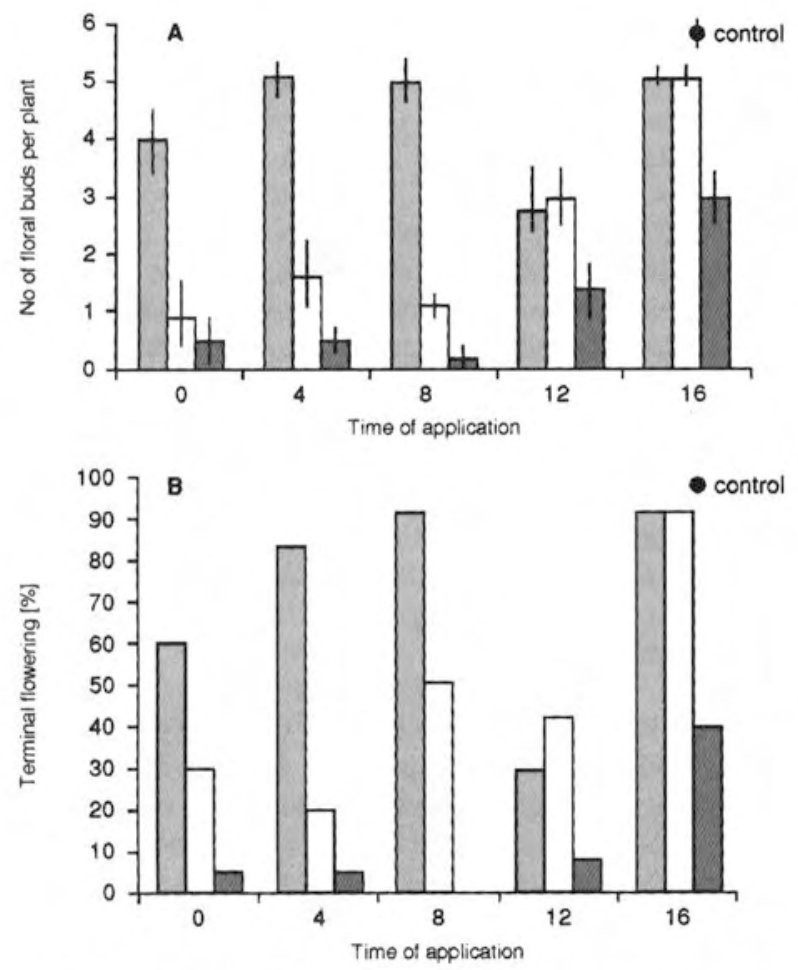

口Ethrel $300 \mathrm{mg}^{-3} \mathrm{dm}^{-3}$ DEthrel $400 \mathrm{mg}^{-3} \mathrm{dm}^{-3}$ QEthrel $500 \mathrm{mg}^{-3} \mathrm{dm}^{-3}$

Fig. 3. Flowering response of Pharbitis nil seedlings to ethrel treatment. Ethrel was applied on cotyledons during $16 \mathrm{~h}$ inductive night. The values are mean for 15 replicates \pm SE. A - Number of floral buds per plant, B - Terminal flowering.

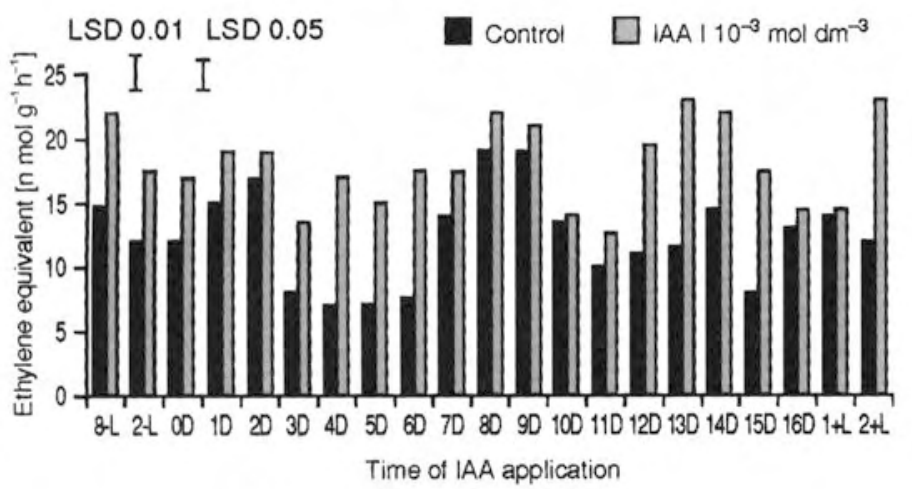

Fig. 4. Endogenous ethylene production by Pharbitis nil seedlings as a result of IAA application. IAA was applied every hour during $16 \mathrm{~h}$ long dark period and during a few hours before and after inductive night. The seedlings were harvested after IAA application and closed in glass jars for $3 \mathrm{~h}$ incubation period. Then ethylene was measured by gas chromatography method.

$\mathrm{L}$ - light period before or after inductive night; $\mathrm{D}$ - inductive night.

(Fig. 7). Moreover, the influence of $\mathrm{AgNO}_{3}$, the inhibitor of ethylene action and its interaction with auxin were investigated. When the cotyledons were first treated with auxin, and after 30 minutes with $\mathrm{AgNO}_{3}$ the inhibition of flowering was reversed in the 8th and 12th hour of the inductive night (Fig. 8). Both $\mathrm{CoCl}_{2}$ and $\mathrm{AgNO}_{3}$ applied without auxin had no influence on the flowering of Pharbitis nil.

\section{DISCUSSION}

There are only very few works concerning the role of endogenous ethylene in the induction of flowering (Suge 1977;

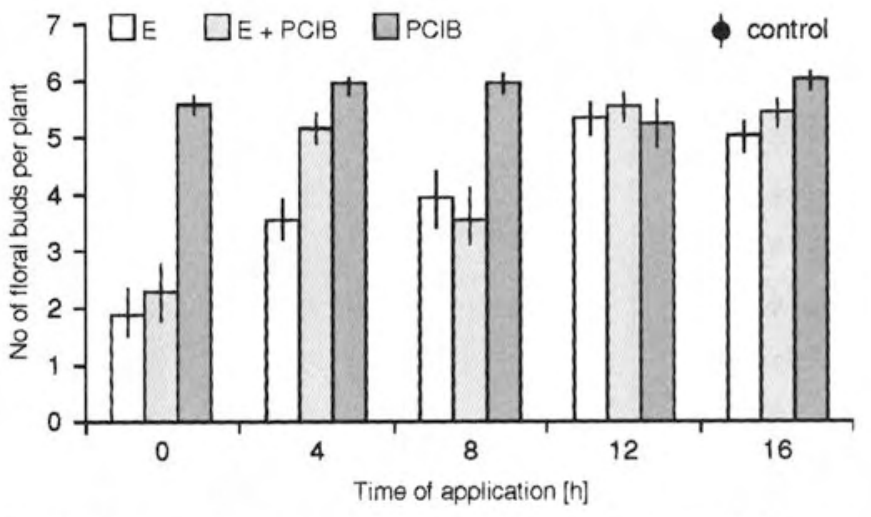

Fig. 5. Flowering response of Pharbitis nil seedlings to ethrel (E) application $\left(400 \mathrm{mg}^{*} \mathrm{dm}^{-3}\right)$ on cotyledons and PCIB $\left(10^{-3} \mathrm{~mol}^{*} \mathrm{dm}^{-3}\right)$ to shoot tips during inductive night. The values are mean for 15 replicates $\pm \mathrm{SE}$.

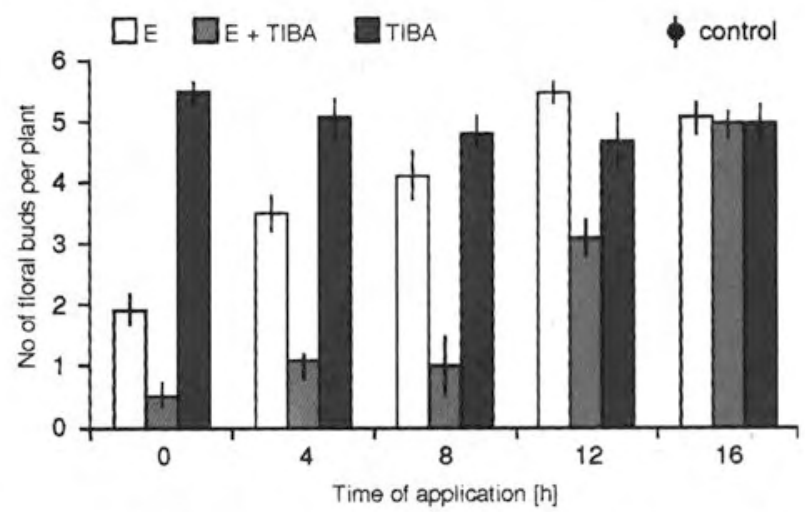

Fig. 6. Flowering response of Pharbitis nil seedlings to ethrel (E) $\left(400 \mathrm{mg}^{*} \mathrm{dm}^{-3}\right)$ application on cotyledons and TIBA $\left(10^{-3} \mathrm{~mol}^{*} \mathrm{dm}^{-3}\right)$ on cotyledon petioles during inductive night. The values are mean for 15 replicates $\pm \mathrm{SE}$.

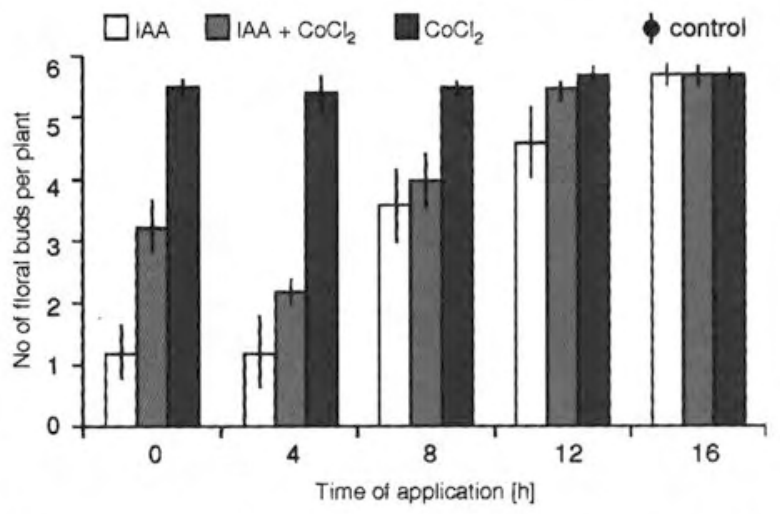

Fig. 7. Flowering response of Pharbitis nil seedlings to IAA $\left(10^{-3}\right.$ $\left.\mathrm{mol}^{*} \mathrm{dm}^{-3}\right)$ and $\mathrm{CoCl}_{2}\left(10^{-3} \mathrm{~mol}^{*} \mathrm{dm}^{-3}\right)$ application on cotyledons during inductive night. The values are mean for 15 replicates \pm SE.

De Greef et al. 1983). It has been stated in the present work that the level of endogenous ethylene in the seedlings of Pharbitis nil is generally low. Halevy et al. (1991) suggest that a low level of endogenous ethylene is necessary for the induction of flowering to take place. On the other hand it is widely known that ethylene accelerates senescence and other physiological phenomena (Abeles et al. 1992). So it could not be excluded that the level of endogenous ethylene, increasing with an age of plant, is responsible for the loss of seedlings sensitivity to the photoperiodic induction of flowering (Vangronsveld 1988). 


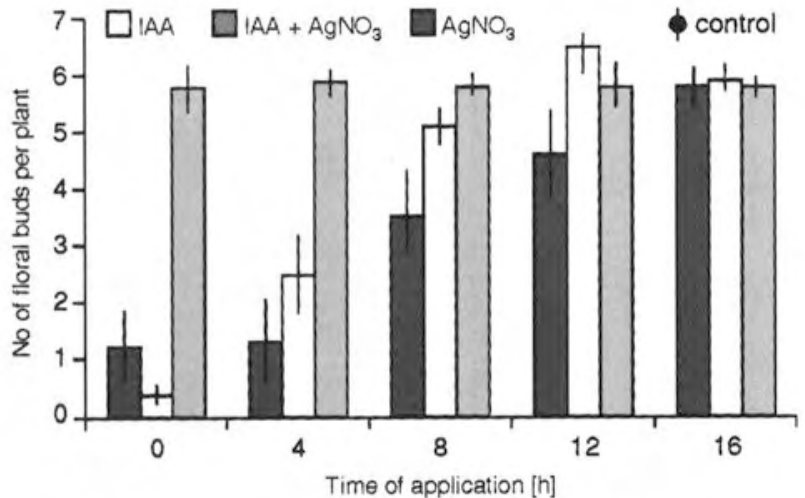

Fig. 8. Flowering response of Pharbitis nil seedlings to IAA $\left(10^{-3}\right.$ $\left.\mathrm{mol}^{*} \mathrm{dm}^{-3}\right)$ and $\mathrm{AgNO}_{3}\left(10^{-3} \mathrm{~mol}^{*} \mathrm{dm}^{-3}\right)$ application on cotyledons during inductive night. The values are mean for 15 replicates \pm SE.

It has been shown (Fig. 1) that the production of endogenous ethylene is several times higher in the second half of an inductive night than in the first one. At the same time exogenous ethylene strongly inhibits the flowering just during the first half of the night. Thus it follows that applying exogenous ethylene to a plant having low content of endogenous ethylene, it means increasing its tissue concentration at that special time, causes the inhibition of flowering (Fig. 3). It is known that the influence of ethylene on the flowering is dependent on its concentration (Suge 1974). It has been pointed out (Fig. 3) that ethrel is the most effective at high concentrations of 400 and $300 \mathrm{mg}^{*} \mathrm{dm}^{-3}$, and does not show an inhibiting effect at 100 and $200 \mathrm{mg}^{*} \mathrm{dm}^{-3}$ (data not presented).

Also the attempt has been undertaken to show the interaction of auxin and ethylene in the inhibition of flowering. The inhibiting effect of auxin on the flowering of Pharbitis nil has been reported many times (Ogawa 1967; Friedman et al. 1990; Halevy et al. 1991; Kulikowska-Gulewska et al. 1995). Ethylene also exerted an inhibiting effect on the flowering of Pharbitis nil (Suge 1972; Aharoni et al. 1985; Lay-Yee et al. 1987). It is generally known that auxins and ethylene influence in many ways each other in a plant (Abeles et al. 1992). However, the detailed role of ethylene in the auxin-inhibition of flowering has not been determined yet. It has been shown (Fig. 4) that the application of IAA during the inductive night causes an intensive synthesis of ethylene. It is in agreement with the earlier reports (Abeles 1973; Smulders et al. 1990; Halevy et al. 1991). The most active is the auxin applied in the first half of an inductive night, between the 3rd and the 6th hour (Fig. 4), increasing the production of ethylene more than twice. At the same time the level of endogenous auxin in Pharbitis cotyledones is low (KulikowskaGulewska et al. 1995). When the level of endogenous auxin increased in the 8th-12th hour of night (Kulikowska-Gulewska et al. 1995), the application of exogenous auxin influences only slightly the ethylene production (Fig. 4). On the other hand, however, Halevy et al. (1991) suggested that the inhibition of flowering caused by auxin was not connected with the increase in ethylene production. However it is known that the biosynthesis of ethylene is controlled by two families of genes which display tissue-specific as well as developmentally-regulated expression and this in turn causes the differentiated reactions of plants to ethylene (Woltering, de Vrije 1995).

In order to better understand the interactions between auxin and ethylene, the experiments with the antagonists of both the compounds have been conducted. It has been observed (Fig. 5) that the simultaneous application of ethrel (to cotyledons) and PCIB (to shoot apex) caused that PCIB reversed at the 4 th hour of night the unfavourable influence of ethylene on the flowering of Pharbitis nil (Fig. 5). On the other hand the joint application of ethrel and TIBA on the cotyledons causes much greater degree of inhibition during the whole long inductive night (Fig. 6). It seems that this sinergistic action of ethrel and TIBA could be a result of auxin polar transport inhibition. In such situation auxin remains in cotyledons where could stimulate the ethylene production. The inhibiting effect of IAA on the flowering was also partially overcome by treating the seedlings with $\mathrm{CoCl}_{2}$, the inhibitor of ethylene biosynthesis (Fig. 7). Similar results were obtained in experiments with $\mathrm{AgNO}_{3}$, the inhibitor of ethylene action (Fig. 8). Treating the seedlings only with the inhibitors of auxins and of ethylene did not cause any effect on the induction of flowering (Figs 5-8). It has been shown that the ethylene production induced by auxins is connected with the inhibition of flowering in Xanthium (Abeles 1967) and other plants (Machackova et al. 1986). Recently Wijayanti et al. (1997) have also stated that the inhibiting effect of auxin on the flowering of Pharbitis could be the result of an increased ethylene biosynthesis.

The all obtained in the present paper results show that ethylene could participate in the control of flowering induction in a short day plant Pharbitis nil, and that auxin may exert its inhibiting influence on the flowering through the action of ethylene.

\section{ACKNOWLEDGEMENTS}

This research was supported by grant No 6PO4C05009 from the Polish Committee for Scientific Research (KBN).

\section{LITERATURE CITED}

ABELES F.B. 1967. Inhibition of flowering in Xanthium pensylvanicum Walln. by ethylene. Plant Physiol. 42: 608-609.

ABELES F.B. 1973. Ethylene in plant biology. Academic Press. New York and London.

ABELES F.B., Morgan P.W., Saltveit M.E.Jr. 1992. Ethylene in plant biology. Second Edition. Academic Press Inc. San Diego New York Boston London Sydney Tokyo Toronto.

AHARONI M., GOLDSCHMIDT E.E., HALEVY A.H. 1985. Changes in metabolites of acetate $-1-\mathrm{C}^{14}$ following floral induction of Pharbitis nil. J. Plant Physiol. 120: 145-152.

COCKSHULL K.E. 1978. 2-chloroethylphosphonic acid and flower initiation by Chrysanthemum morifolium Ramat. in short days and long days. J. Hort. Sci. 53: 85-90.

DE GREEF J.A.,VAN DIJCK R., DE PROFT M.P., MEKERS O. 1983. Flowering maturity and ethylene production capacity of $\mathrm{Ae}$ chmea victoriana through ACC application. Acta Hort. 137: 211216.

FRIEDMAN H., SPIEGELSTEIN H., GOLDSCHMIDT E.E., HALEVY A.H. 1990. Flowering response of Pharbitis nil to agents affecting cytoplasmic pH. Plant Physiol. 94: 114-119.

GALANG F.G., AGATI J.A. 1936. A progress report on the influence of heat and smoke on the development of Carabao Mango buds. Philippine J. Agric. 7: 245-261.

GASPAR T.H., CREVECOEUR M., PENEL C., GREPPIN H. 1986. Ethylene production in spinach leaves during floral induction. $\mathrm{J}$. Exp. Bot. 37: 1218-1224.

HALEVY A.H., SPIEGELSTEIN H.H., GOLDSCHMIDT E.E. 1991. Auxin inhibition of flower induction of Pharbitis is not mediated by ethylene. Plant Physiol. 95: 652-654.

KHATOON S., SEIDLOVA F., KREKULE J. 1973. Time - dependence of auxin and ethrel effects on flowering of Chenopodium rubrum L. Biol. Plant. 15: 361-363. 


\section{KULIKOWSKA-GULEWSKA H., CYMERSKI M., CZAPLEWSKA} J., KOPCEWICZ J. 1995. IAA in the control of photoperiodic flower induction of Pharbitis nil Chois. Acta Soc. Bot. Pol. 64(1): 4550.

LAY-YEE M., SACHS R.M., REID M.S. 1987. Changes in cotyledon in mRNA during ethylene inhibition of floral induction in Pharbitis nil strain Violet. Plant Physiol. 85: 545-548.

MACHACKOVA I., KREKULE J., SOUCKOVA D., PRIKRYL Z., ULLMANN J. 1986. Reversal of IAA-induced inhibition of flowering by aminoethoxyvinylglycine in Chenopodium. J. Plant Growth Regul. 4: 203-209.

MICHNIEWICZ M., ROŻEJ B. 1989. Interactions of abscisic acid and ethylene in the growth and development of Fusarium culmorum (W.G.Sm.) Sacc. Bull. Pol. Acad. Sci. Biol. Sci. 37(7-9): 193-199.

OGAWA Y.I. 1967. The relation of growth regulators to flowering: auxin. In: Imamura S. (ed.), Physiology of flowering in Pharbitis nil, Japanese Society of Plant Physiologists. Tokyo: 107-108.

RODRIGUEZ A.B. 1932. Smoke and ethylene in fruiting of pineapple. J. Dept. Agr. Puerto Rico 26: 5-18.

SMITH A.R., HALL M.A. 1984. Biosynthesis and metabolism of ethylene. In: The biosynthesis and metabolism of plant hormones. Society for Experimental Biology Seminar Series. Crozier A. Hillman J.R. (ed.). Cambridge University Press, Cambridge, Vol. 23: 201-229.
SMULDERS M.J.M., KEMP A., BARENDSE G.W.M., CROES A.F., WULLEMS G.J. 1990. Role of ethylene in auxin-induced flower bud formation in tobacco explants. Physiol. Plant. 78: 167-172.

SUGE H. 1974. Nature of ethylene inhibition of flowering in Pharbitis nil. In: Plant growth substances. 1973. Proceedings 2nd International Conference on Plant Growth Substances. 960-966 Hirokawa Publ. Co. Tokyo.

SUGE H. 1977. Changes in ethylene production of vernalized plants. Plant Cell Physiol. 18: 1167-1171.

SUGE H.A., AMAGASA T. 1987. The mode of flower inhibiting action of ethylene in Pharbitis nil. Plant Cell Physiol 28: 1159-1161.

VANGRONSVELD J., CLIJSTERS H., VAN POUCKE J. 1988. Phytochrome controlled ethylene biosynthesis of intact etiolated bean seedlings. Planta 174: 19-24.

WIJAYANTI L., FUJIOKA S., KOBAYASHI M., SAKURAI A. 1997. Involvement of abscisic acid and indole -3 -acetic acid in the flowering of Pharbitis nil. J. Plant Growth. Regul. 16: 115-119.

WOLTERING E.J., DE VRIJE T. 1995. Ethylene: a tiny molecule with great potential. BioEssays, 17(4): 287-290.

YOSHII H., IMASEKI H. 1981. Biosynthesis of auxin-induced ethylene. Effects of indole-3-acetic acid, benzyladenine and abscisic acid in endogenous levels 1-aminocyclopropane-1-carboxylic acid (ACC) and ACC-synthase. Plant Cell Physiol. 22: 369-379.

\section{ETYLEN W KONTROLI FOTOPERIODYCZNEJ INDUKCJI KWITNIENIA U PHARBITIS NIL CHOIS}

\section{STRESZCZENIE}

Zawartość endogennego etylenu w siewkach Pharbitis nil poddanych indukcyjnej $16 \mathrm{~h}$ nocy jest niska w pierwszej połowie okresu ciemnego, po czym znacznie wzrasta w drugiej połowie nocy. Ethrel, związek uwalniający etylen, podany na liścienie siewkom zwiększa ilość etylenu w siewkach i jednocześnie hamuje kwitnienie, szczególnie w pierwszej połowie indukcyjnej nocy, gdy zawartość endogennego etylenu w siewkach jest niska.

Auksyna hamując kwitnienie Pharbitis, powoduje jednocześnie zwiększenie produkcji endogennego etylenu. PCIB, inhibitor działania auksyny odwraca hamujący wpływ ethrelu na kwitnienie. Natomiast łączne podanie ethrelu i TIBA, inhibitora polarnego transportu auksyn, powoduje zwiększenie inhibicji kwitnienia.

$\mathrm{CoCl}_{2}$, inhibitor biosyntezy etylenu oraz $\mathrm{AgNO}_{3}$, inhibitor działania etylenu częściowo znoszą hamujący wpływ auksyny na kwitnienie.

Uzyskane wyniki sugerują udział etylenu w kontroli fotoperiodycznej indukcji kwitnienia.

SŁOWA KLUCZOWE: etylen, auksyna, indukcja fotoperiodyczna, Pharbitis nil. 